\title{
The Giant Sucking Sound: Is China Diverting Foreign Direct Investment from Other Asian Economies?*
}

Busakorn Chantasasawat

East Asian Institute

National University of

Singapore

eaicb@nus.edu.sg

\section{K. C. Fung}

Professor of Economics

Santa Cruz Center for

International Economics (SCCIE)

University of California,

Santa Cruz

kcfung@ucsc.edu

and

Senior Research Fellow

Hong Kong Institute of

Economics and

Business Strategy (HKIEBS)

The University of Hong Kong

\section{Hitomi lizaka}

Hong Kong Institute of Economic and

Business Strategy (HKIEBS)

The University of Hong Kong iizaka@sbcglobal.net

\section{Alan Siu}

School of Economics and

Finance

The University of Hong Kong asiu@econ.hku.hk

\begin{abstract}
This paper attempts to determine empirically whether China is taking foreign direct investment (FDI) away from other Asian economies (the "China effect"). A random-effects simultaneous equation model, controlling for the determinants of inward FDI of eight East and Southeast Asian economies over 1985-200I and using China's inward FDI as an indicator of the China effect, indicates that China's FDI level is positively related to these economies' FDI levels and negatively related to their shares in FDI in Asia. Moreover, openness, corporate tax rates, and corruption can exert a greater influence on these countries' FDI than China's FDI.
\end{abstract}

\section{Introduction}

In recent years, China has become a favorite destination for foreign direct investment (FDI). In 2002, FDI in China reached US\$53 billion. For 2003, despite the problems associated with SARS (severe acute respiratory syndrome), China received US\$54 billion worth of FDI, which was substantially larger than the US\$30 billion received by the United States.

\footnotetext{
* This is a revised version of a paper presented at the sixth Asian Economic Panel meeting on 9-10 October 2003 in Seoul, South Korea. We appreciate the comments from Wing Thye Woo, Marcus Noland, Gordon de Brouwer, Yunjong Wang, Chan Kang, Chou Ji, Yiping Huang, Xiao Geng, Sylvie Démurger, Fredrik Sjöholm, Angang Hu, and other participants at the conference. This research is supported by the Asian Economic Panel and by a grant from the University Grants Committee of the Hong Kong Special Administrative Region, China (Project No. AoE/H-05/99).
} 
Most of China's Asian neighbors are worried about the prospect of China's becoming "the factory of the world." Several Asian governments have publicly noted that China's economic rise and its attractiveness as a location for low-cost export platforms have diverted direct investment away from their economies. Policymakers throughout the region are convinced that the rise of China has contributed to the "hollowing out" phenomenon; that is, foreign and domestic investors have been withdrawing funds and relocating production from their own countries and investing in China instead. This has led to continued loss of manufacturing industries and jobs, further weakening the vitality of these economies. ${ }^{1}$

In this paper, we examine empirically the question of this "China effect"; in particular, whether China has diverted FDI away from a group of eight East and Southeast Asian economies (Hong Kong, Taiwan, South Korea, Singapore, Malaysia, Indonesia, the Philippines, and Thailand). The research strategy is to control for the standard determinants of FDI, add a proxy to represent the China effect, and investigate the sign, significance, and magnitude of this effect.

\section{Literature review and policy concerns}

Many analysts, commentators, and policymakers in Asia have voiced concerns about the economic rise of China and China's possible adverse affect on direct investment flows into their countries. In November 2002, the Deputy Prime Minister of Singapore, Lee Hsien Loong (who has since become the Prime Minister of Singapore), commented that "Southeast Asian countries are under intense competitive pressure, as their former activities, especially labor-intensive manufacturing, migrate to China. One indicator of this massive shift is the fact that Southeast Asia used to attract twice as much FDI as Northeast Asia, but the ratio is reversed." 2 According to KOTRA, the state-run trade and investment promotion agency of South Korea, the growth rate of FDI in most Asian countries is falling as global investors are being drawn to invest in China. ${ }^{3}$ The World Economic Forum director for Asia, Frank J. Richter, said that if the Asian countries do not take prudent and pragmatic

1 The trade and investment relationship between China and the Southeast Asian economies is expected to intensify, as a result of the accord signed by China and the Association of Southeast Asian Nations (ASEAN) on 29 November 2004 that is aimed at creating a free trade area by 2010. Recent literature related to the impact of the rise of China on other economies include McGibbin and Woo (2003), Chantasasawat et al. (2004a, 2004b), and Eichengreen and Tong (2005).

2 "China's Rise Is the Most Dramatic Change in Asia," ChinaOnline, 14 November 2002.

з Sung-jin Kim, "Foreign Investment Likely to Fall," The Korea Times, 26 August 2002. 
steps to be as competitive as China, the FDI flows into these economies would be adversely affected. ${ }^{4}$ Taiwan's Vice Premier, Lin Hsin-I, said that given the rapid rise of the mainland Chinese economy, Taiwan would have to take effective measures to increase its competitiveness. Taiwan has to implement the "Go South" policy to encourage Taiwanese to switch their investments from the mainland to Southeast Asian countries. ${ }^{5}$

What determines FDI flows into Asian (and other) economies? Is there a China effect? To gain some insight concerning the methodology we should use to answer these questions, in particular the appropriate explanatory variables, we briefly review some relevant academic literature.

Brainard (1997) empirically examines the determinants of the ratio of U.S. export sales to total foreign sales (the sum of exports and sales by foreign affiliates by industry). She uses a framework that focuses on factors that favor concentration of production (i.e., factors that favor export sales) versus proximity to overseas customers (i.e., factors that favor sales by foreign affiliates). The explanatory variables include freight costs to the export market, tariffs of the host country, per capita gross domestic product, corporate tax rates, measures of trade and FDI openness, and measures of plant scale economies and corporate scale economies. She also includes a dummy representing whether a country has experienced a political coup in the last decade. In her random-effects estimation, almost all the variables have the right signs and are significant. The major exception is the corporate tax rate, which has the opposite sign, as predicted.

Gastanaga, Nugent, and Pashamova (1998) focus on policy reforms in developing countries as determinants of FDI inflows. They employ both ordinary-least-squares and panel estimations. Expected rates of growth, corporate tax rates, degree of corruption, and degree of openness to FDI are all important determinants of FDI flows into these economies. Hines (1995) and Wei (1997) both examine the impact of institutional factors on FDI. By employing a corruption index, Hines shows that after 1977, U.S. FDI grew faster in less-corrupt countries. Wei (1997) uses OECD direct investment data and shows that both corruption and tax rates have negative effects on FDI flows. Wei's estimations are cross-sectional. ${ }^{6}$

\footnotetext{
4 "Future Flows of FDI into Asian Economies to Depend on China," New Straits TimesManagement Times, 9 March 2002.

5 “Taiwan to Improve Competitiveness," Taiwanese Central News Agency, 21 November 2002.

6 Other related literature includes Bao et al. (2002), Fung, lizaka, and Siu (2003), and Zhang and Song (2001).
} 


\section{The empirical model}

In this section we describe the econometric model we use to estimate the impact of FDI in China on the inward direct investment in various Asian economies. The economies we examine are those of Hong Kong, Singapore, Taiwan, South Korea, Thailand, Malaysia, the Philippines, and Indonesia. Data are from 1985 to 2001. Our strategy is to control for all the standard explanatory variables of FDI in the Asian economies, and we add an additional variable representing the China factor. The level of inflow of China's FDI is our proxy for the China factor. Obviously, Chinese inward FDI can be dependent on the inward direct investment of our group of Asian economies as well as on the standard explanatory variables. To capture such a reciprocal relationship between the inflow of FDI in China and that of the other Asian economies, the FDI equations for both the Asian economies and China are estimated simultaneously.

The basic regression models for inward FDI for the Asian countries and for China are written as linear specifications of the following form:

$$
\begin{aligned}
\ln \left(\text { AFDI }_{i, t}\right) & =\alpha_{0}+\alpha_{1} \ln \left(\text { CHINA_FDI }_{t}\right)+\beta_{1} \ln \left(\text { AGROWTH }_{i, t}\right)+\beta_{2} \ln \left(\text { ACORRUPT }_{i, t}\right) \\
& +\beta_{3} \ln \left(\text { ADUTY }_{i, t}\right)+\beta_{4} \ln \left(\text { AGOV }_{i, t}\right)+\beta_{5} \ln \left(\text { AWAGE }_{i, t}\right) \\
& +\beta_{6} \ln \left(\text { AOPEN }_{i, t}\right)+\beta_{7} \ln \left(\text { AILLIT }_{i, t}\right)+\beta_{8} \ln \left(\text { ACPTAX }_{i, t}\right)+\beta_{9} \ln \left(\text { ATEL }_{i, t}\right) \\
& +\beta_{10} \ln \left(\text { AINCOME }_{i, t}\right)
\end{aligned}
$$

$$
\begin{aligned}
\ln \left(\text { CHINA_FDI }_{t}\right) & =\gamma_{0}+\delta_{1} \ln \left(\text { AFDI }_{i, t}\right)+\rho_{1} \ln \left(\text { CGROWTH }_{t}\right)+\rho_{2} \ln \left(\text { CCORRUPT }_{t}\right) \\
& +\rho_{3} \ln \left(\text { CDUTY }_{t}\right)+\rho_{4} \ln \left(\text { CGOV }_{t}\right)+\rho_{5} \ln \left(\text { CWAGE }_{t}\right)+\rho_{6} \ln \left(\text { COPEN }_{t}\right) \\
& +\rho_{7} \ln \left(\text { CINCOME }_{t}\right),
\end{aligned}
$$

where the subscripts stand for country $i$ at period $t$. Variables beginning with the letter " $\mathrm{A}$ " denote variables of the Asian countries, and those beginning with the letter "C" denote variables of China. ${ }^{7}$ (See appendix A for descriptions of variables.)

$7 A^{\prime} F D I_{i, t}=$ the level of inward FDI in the $i$ th Asian economy at time $t ; C H I N A \_F D I_{t}=$ inward FDI into China in year $t$; GROWTH $H_{i, t}=$ growth rate of GDP of country $i$ at time $t$;

CORRUPT $_{i, t}=$ an index of corruption of country $i$ at time $t$; DUTY $Y_{i, t}=$ import duty of country $i$ at time $t ; W A G E_{i, t}=$ average wage in manufacturing of country $i$ at time $t ; O P E N_{i, t}=$ the share of exports and imports in GDP of country $i$ at time $t ; I L L I T_{i, t}=$ the percentage of people who are illiterate in country $i$ at time $t ; C P T A X_{i, t}=$ corporate tax rate of country $i$ at time $t ; G O V_{i, t}=$ an index of government stability of country $i$ at time $t ; T E L_{i, t}=$ number of telephone mainlines per 1,000 people of country $i$ at time $t$; INCOME $E_{i, t}=$ per capita GDP of country $i$ at time $t$. 
The independent variables examined in the analysis are believed to exert an influence on inward FDI in each Asian country and in China by changing the investment environment through institutional and policy changes and through economic conditions. The main variable that we examine in this paper is the proxy for the China effect, CHINA_FDI. Two important aspects of increases in China's FDI should be considered in our analysis. First, when multinational enterprises (MNEs) are deciding on a low-wage export platform, they may choose between investing in China and investing in another Asian country, say Thailand. In this case, the MNEs will study a whole set of factors (e.g., wage rates, political risks, and infrastructure) that make a country desirable as a site for low-cost production, and a decision to invest in China will result in a reduction of the FDI in Thailand. The sign of CHINA_FDI, according to this argument, is negative. We call this the investment-diversion effect.

A second aspect of increased FDI in China concerns the production and resource linkages between a growing China and the rest of Asia. In manufacturing, this takes the form of further specialization and increasing fragmentation of the production processes. Suppose that an investor sets up factories in both China and Thailand to take advantage of their respective competitiveness in distinct stages of production. Components and parts are then traded among China and other Asian economies. An increase in China's FDI is then positively related to an increase in Thailand's FDI. A different but complementary argument is that as China grows, its market size increases and its appetite for minerals and resources also increases. Subsequently, foreign firms rush into China to produce and sell in China. At the same time, other multinationals invest in other parts of Asia to extract minerals and resources to export to a fast-growing China in need of a whole spectrum of raw materials. This line of reasoning leads one to predict that the sign of CHINA_FDI will be positive. We call this effect the investment-creation effect. Theoretically, we cannot determine a priori the net effect of investment creation and investment diversion for China; this issue must be examined empirically.

A substantial literature confirms empirically the importance of both the current market size and the growth factor of the host economy, as measured by GDP per capita and GDP growth rate, respectively. Foreign investors that target local markets are assumed to be more attracted to a country with a higher GDP growth rate because it indicates a larger potential demand for their products. The effect of this variable on their investment incentive, therefore, is assumed to be larger than the effect of this variable on the incentive of foreign investors who are not local-market seekers. Furthermore, for foreign investors who operate in industries characterized by relatively large economies of scale, the importance of the host country's current market size and its economy's potential for growth is magnified. This is because such investors 
can exploit scale economies only after the market attains a certain threshold size. In our analysis, per capita GDP and growth rate of GDP are used as indicators for current market size and market potential for the products of foreign investors, respectively. Thus the expected signs for these variables are positive.

Because the cost of labor is a major component of the cost function, various versions of wage variables are frequently tested in the literature. A high nominal wage, other things being equal, deters inward FDI. This is true particularly for the firms that engage in labor-intensive production activities. Therefore, conventionally, the expected sign for this variable is negative. However, the results of various empirical analyses of the effect of labor cost on investment incentives are not in agreement. Some studies indicate that there is no significant correlation between labor costs and inward FDI, whereas others demonstrate a positive relationship between these variables. The latter result is often attributed to an advanced level of labor productivity or high quality of human capital that may be reflected in the wage variables (e.g., cases in which highly skilled labor is actively sought by foreign investors). Our analysis makes use of average wages in the manufacturing sector.

The level of human capital is demonstrated to be an important determinant of the marginal productivity of capital. Various studies show that skill-related variables are host-country specific. When a host country is more appealing to foreign investment in production that requires a relatively low level of skills, the importance of the human capital variable tends to be small. Labor skills can be a more significant factor for a host country in which more capital- and technology-intensive investment projects are concentrated. In this analysis, we utilize the illiteracy rate as a proxy for the level of human capital.

We examine the hypothesis that better-developed regions with a superior quality of infrastructure are more attractive to foreign firms relative to others by including in our regressions a proxy for developed infrastructure, the number of telephone mainlines per 1,000 people.

We also examine the significance of institutional factors in the determination of FDI by incorporating indexes of the level of corruption and of the stability of each government into the regressions. Corruption can discourage FDI by inducing a higher cost of doing business. Hines (1995) shows that FDI originating from the United States grew more rapidly in less-corrupt countries than in more-corrupt countries after 1977. Wei (1997) presents an alternative explanation of the large negative and significant effect of corruption on FDI. Unlike taxes, corruption is not transparent and involves many arbitrary factors. The agreement between a briber and a corrupt 
official is hard to enforce and creates more uncertainty about the total questionable payments or the final outcome. Wei demonstrates that this type of uncertainty induced by corruption leads to a reduction in FDI. The political stability of a government can be another important factor in fostering the inflow of FDI. Uncertain political environments and their related risks can impede FDI inflows in spite of favorable economic conditions. Because the indexes of corruption and instability assign higher scores to less-corrupt or more-stable countries, the expected signs of the variables ACORRUPT and AGOV are positive.

Also included in the analysis are policy-related variables: tariff barriers (proxied by import duty), corporate tax rates, and openness to foreign trade. The effect of tariffs on the behavior of MNEs is methodologically demonstrated by Horst (1971). He predicts that in the face of higher tariffs imposed by the host countries, other things being equal, MNEs will increase their production abroad and decrease their exports. More recent models highlight the effect of tariffs on FDI in the context of vertical and horizontal specialization within MNEs. An MNE engaged in vertical FDI typically organizes its individual affiliates so that they specialize in different stages of production of the output, and semi-finished products in turn are exported to other affiliates for further processing. By fragmenting the production process, the parent organizations and their affiliates take advantage of factor price differentials across countries. FDI by an MNE with horizontal specialization, on the other hand, involves the MNE's affiliates' being engaged in similar types of production. An MNE engaged in horizontal FDI is generally associated with market-seeking behavior and its motivation is to avoid trade costs. The choice between engaging in horizontal FDI or exporting involves comparing the relative advantages of minimizing trade costs with the savings resulting from economies of scale.

The MNEs that utilize vertical production networks might find it beneficial to invest in countries with relatively low tariff barriers because this would result in lower costs for their imported intermediate products. Therefore, in this case the expected sign of ADUTY is negative. In contrast, MNEs engaged in horizontal FDI would likely regard high tariff barriers as an incentive to replace their exports with production abroad by their foreign affiliates (Brainard 1997; Carr, Markusen, and Maskus 2001). Such tariff-jumping would imply a positive relationship between ADUTY and FDI.

AOPEN is included in the regressions to examine the importance of openness of an economy to international trade. This variable measures the degree of general trade restrictions of each country. Following the same line of reasoning above, a negative relationship between openness and market-seeking FDI is expected, and a positive relationship is expected for export-oriented FDI. 
Another policy-related variable that can influence the host country's location advantage is the host country's corporate (or other) tax rates. The MNEs, as global profit maximizers, can be assumed to be sensitive to tax factors, because taxes have a direct effect on their profits. Evidence for significant negative influences of corporate tax rates is reported in Wei (1997), Gastanaga, Nugent, and Pashamova (1998), and Hsiao (2001).

All variables are transformed into logarithms. Data sources and additional explanations of variables are given in appendix A.

In our estimations, we assume for each FDI equation that there is a collection of factors that are omitted from the regression, and these factors are specific to each individual country. Therefore, we estimate equations that take the following form:

$$
y_{i t}=\alpha+\beta^{\prime} x_{i t}+\varphi_{i}+\epsilon_{i t},
$$

where the disturbance term, $\epsilon_{i t}$, is associated with both time and the cross-sectional units, and $\varphi_{i}$ is the random disturbance that is associated with the $i$ th country and is assumed to be constant through time. In other words, the country-specific constant terms are assumed to be randomly distributed across the cross-sectional units.

The formulation of the model is specified as follows.

$$
\begin{gathered}
\ln \left(\text { AFDI }_{i, t}\right)=a_{0}+a_{1} \ln \left(\text { CLNFD }_{i, t}\right)+\ln \boldsymbol{X}_{i, t} \mathbf{b}_{i}+u_{i}+e_{i, t} \\
\ln \left(\text { CLNFD }_{i, t}\right)=\gamma_{0}+\gamma_{1} \ln \left(A F D I_{i, t}\right)+\ln Z_{i, t} \boldsymbol{\rho}_{i}+v_{i}+w_{i, t},
\end{gathered}
$$

where $X$ and $Z$ are vectors of explanatory variables from equations (1) and (2), respectively; $e_{i, t}$ and $w_{i, t}$ are disturbance terms, and $u_{i}$ and $v_{i}$ are the individualcountry-effect terms. The above simultaneous equation system is estimated by a two-stage least-squares regression (2SLS).

\section{Results}

\section{I Regressions using levels of FDI inflows}

Table 1 shows the results from the first set of random-effects simultaneous regressions using the levels of FDI inflows as the dependent variables. To avoid a multicollinearity problem, variables that are highly correlated are not included simultaneously. Therefore AWAGE, AINCOME, ATEL, and AOPEN are not all included at the same time in the same specifications. For each of the dependent variables, there are five specifications. Specification (1) includes AWAGE but not ATEL 
Table 1. Level of FDI inflows. Random-effects two-stage least-squares regressions (level of FDI inflows = dependent variable)

\begin{tabular}{|c|c|c|c|c|c|}
\hline Independent variables & (1) & (2) & (3) & (4) & (5) \\
\hline CHINA_FDI & $\begin{array}{l}0.4725^{\text {***}} \\
(7.49)\end{array}$ & $\begin{array}{l}0.4961^{* * *} \\
(7.48)\end{array}$ & $\begin{array}{l}0.5684^{* * *} \\
(7.81)\end{array}$ & $\begin{array}{l}0.4907^{* * *} \\
(7.71)\end{array}$ & $\begin{array}{l}0.5182^{* * *} \\
(7.53)\end{array}$ \\
\hline AGROWTH & $\begin{array}{l}0.4543 \\
(0.58)\end{array}$ & $\begin{array}{l}0.6442 \\
(0.82)\end{array}$ & $\begin{array}{l}0.3867 \\
(0.44)\end{array}$ & $\begin{array}{l}0.5461 \\
(0.69)\end{array}$ & $\begin{array}{l}0.2643 \\
(0.31)\end{array}$ \\
\hline ACORRUPT & $\begin{array}{l}0.1417 \\
(0.60)\end{array}$ & $\begin{array}{l}0.1906 \\
(0.79)\end{array}$ & $\begin{array}{l}0.4767^{*} \\
(1.81)\end{array}$ & $\begin{array}{l}0.0659 \\
(0.27)\end{array}$ & $\begin{array}{l}0.4121 \\
(1.65)\end{array}$ \\
\hline ADUTY & $\begin{array}{l}0.0971 \\
(0.47)\end{array}$ & $\begin{array}{l}0.1375 \\
(0.67)\end{array}$ & $\begin{array}{l}-0.3904^{*} \\
(-1.94)\end{array}$ & $\begin{array}{l}0.1142 \\
(0.53)\end{array}$ & $\begin{array}{l}-0.2109 \\
(-0.95)\end{array}$ \\
\hline$A G O V$ & $\begin{array}{l}0.1032 \\
(0.63)\end{array}$ & $\begin{array}{l}0.1160 \\
(0.67)\end{array}$ & $\begin{array}{l}0.0014 \\
(0.01)\end{array}$ & $\begin{array}{l}0.0631 \\
(0.38)\end{array}$ & $\begin{array}{l}0.0525 \\
(0.29)\end{array}$ \\
\hline AWAGE & $\begin{array}{l}-0.1635 \\
(-1.41)\end{array}$ & & & & \\
\hline AOPEN & $\begin{array}{l}0.9966^{* * *} \\
(5.72)\end{array}$ & $\begin{array}{l}1.0460^{* * *} \\
(5.35)\end{array}$ & & $\begin{array}{l}0.8717^{* * *} \\
(4.71)\end{array}$ & \\
\hline AILLIT & $\begin{array}{l}0.0509 \\
(0.29)\end{array}$ & $\begin{array}{l}0.0823 \\
(0.47)\end{array}$ & $\begin{array}{l}0.4864^{* * *} \\
(2.72)\end{array}$ & $\begin{array}{l}0.2158 \\
(1.26)\end{array}$ & $\begin{array}{l}0.5056^{\text {** }} \\
(2.92)\end{array}$ \\
\hline АСРТАХ & $\begin{array}{l}-1.2869^{* * *} \\
(-3.42)\end{array}$ & $\begin{array}{l}-1.3944^{* * *} \\
(-3.55)\end{array}$ & $\begin{array}{l}-0.4384 \\
(-1.12)\end{array}$ & $\begin{array}{l}-1.1889^{* * *} \\
(-3.10)\end{array}$ & $\begin{array}{l}-0.4614^{* *} \\
(-1.21)\end{array}$ \\
\hline ATEL & & $\begin{array}{l}-0.1370 \\
(-1.45)\end{array}$ & $\begin{array}{l}0.1809^{* *} \\
(2.21)\end{array}$ & & \\
\hline AINCOME & & & & $\begin{array}{l}-0.0009 \\
(-0.01)\end{array}$ & $\begin{array}{l}0.3097^{* * *} \\
(2.92)\end{array}$ \\
\hline Constant & $\begin{array}{l}2.8792^{*} \\
(1.80)\end{array}$ & $\begin{array}{l}2.1280 \\
(1.43)\end{array}$ & $\begin{array}{l}1.2382^{*} \\
(0.75)\end{array}$ & $\begin{array}{l}1.7436 \\
(1.02)\end{array}$ & $\begin{array}{l}-0.0755 \\
(-0.04)\end{array}$ \\
\hline$R^{2}$ & 0.6919 & 0.6915 & 0.6136 & 0.6857 & 0.6272 \\
\hline$F$-test: $p$-value & 0.0000 & 0.0000 & 0.0000 & 0.0000 & 0.0000 \\
\hline Observations & 130 & 131 & 131 & 131 & 131 \\
\hline
\end{tabular}

Note: $\mathrm{t}$-statistics are shown in parentheses. CHINA_FDI = inward FDI into China. AGROWTH $=$ growth rate of GDP of Asian country. ACORRUPT = index of corruption of each Asian country. ADUTY = import duty of each Asian country. AGOV = index of government stability of each Asian country. AWAGE = average wage in manufacturing of each Asian country. AOPEN = share of exports and imports in GDP of each Asian country. AILLIT = percentage of people who are illiterate in each Asian country. ACPTAX = corporate tax rate of each Asian country. ATEL = number of telephone mainlines per 1,000 people of each Asian country. AINCOME = per capita GDP of each Asian country.

* Statistically significant at the 10 percent level.

** Statistically significant at the 5 percent level.

*** Statistically significant at the 1 percent level.

and AINCOME (column 1). In specification (2), we look at the effect of ATEL and leave out AWAGE and AINCOME. Specification (3) examines ATEL by additionally excluding AOPEN because of its moderate correlation with ATEL. The effect of AINCOME is studied in specifications (4) and (5), with and without the AOPEN variable, respectively. Note that, in an attempt to keep the variables consistent in the equations for Asia and the equations for China, when a particular variable of the Asian equation is of interest, we try to include that same variable in the China equation provided this does not risk significant multicollinearity. For example, ATEL and CTEL are included when attention is given to the effect of infrastructure. 
Our main variable of interest, CHINA_FDI, is positive and highly significant in all specifications. A 10-percent increase in the FDI inflows to China would raise the level of FDI inflows to the eight East and Southeast Asian countries by about 5 to 6 percent, depending on the particular specification. Despite considerable concerns in policy circles that an increase in FDI inflows to China is at the expense of other regional economies, our study shows that these economies can actually benefit from such increases in FDI. This result may be linked to the production-networking activities among Asian countries as well as to the increased demand for resources by a growing China. The evidence for production networking among China and other Asian economies can be found in the substantial two-way trade of intermediate and final goods in the same industries among those countries. These economic ties of mutual dependence have been deepening rapidly since the 1990s, and the significance of the China effect to our Asian countries' FDI inflows may reflect such interdependence. In sum, our empirical study shows that an increase in China's FDI is positively and significantly related to FDI inflows in other Asian economies. Our central result is that the investment-enhancing effect dominates the investmentdiversion effect, so that on net China is a positive force for FDI inflows into other Asian economies.

The effect of openness, denoted by the variable AOPEN, has the expected positive sign and is always significant (when included in the regressions). Openness captures the degree of both tariff and non-tariff measures, including trade impediments. In contrast to the effect of tariff barriers (proxied by the variable ADUTY), the impact of openness to trade on the inflow of FDI is substantial. The results in table 1 suggest that, other things being equal, the marginal effect of trade liberalization of the Asian countries on their FDI inflows is approximately twice as large as that of the China effect. Trade impediments can take various forms, such as local content requirements, technology transfer requirements, and domestic sales and export requirements. Our results imply that reductions in these types of trade barriers can play a vital role in promoting FDI in the Asian countries.

Corporate tax is another variable that is found to exert a large influence on the level of FDI inflows in this analysis. Although many countries offer various forms of tax incentives for foreign investors, corporate tax rates can be considered one of the most influential tools to promote investment because they have a direct impact on the profitability of foreign investment projects.

Unlike the results of many previous studies, our analysis suggests that the growth rate of GDP does not play an important role in attracting FDI. Per capita income, however, is found to be a significant factor, but only in specification (5). This seems 
to suggest that foreign investors' decisions to invest in Asia are more sensitive to current market size than to the market potential for their products.

Infrastructure in the form of communications infrastructure, as roughly measured by ATEL, is significant in specification (3) but not in specification (2) because ATEL is moderately correlated with $A O P E N$. Communications infrastructure appears to be a favorable characteristic for foreign investors, in terms of the magnitude of its effect, but other key variables in the equation overshadow its influence.

Notwithstanding its insignificance in almost all of the specifications, ADUTY reveals its marginally negative effect on FDI in specification (3). Many of the East and Southeast Asian countries examined here are heavily involved in vertical specialization, particularly in the electric and electronics industries. This vertical network is evident in the share of two-way trade in the same industry in the total volume of trade among these Asian nations. A reduction in tariff barriers can stimulate FDI in the host country by lowering the costs associated with intra-firm input trade.

The relatively large positive effect of illiteracy on FDI found in specifications (3) and (5) is puzzling. One possible reason for this relationship is that FDI in the region tends to seek out cheap labor, which is often correlated with high rates of illiteracy.

In the literature, the degree of government instability and the index of corruption are found to be always negatively associated with the level of FDI. However, neither of these institutional factors (the AGOV or ACORRUPT variables) appears to have an important effect in specifications (1) to (5). In other words, corruption or government instability is unlikely to have significantly discouraged FDI in this group of countries.

Table 1 shows the results of the basic core set of our empirical exercises. We also explore alternative ways and robustness checks of testing for the China effect and in the following sections report the results of regressions that (1) exclude Hong Kong from the sample; (2) define the dependent variable as the eight East and Southeast Asian countries' shares in FDI inflows to Asia; and (3) include a new variable, the total global supply of FDI (OUTFLOW).

\subsection{Regressions without Hong Kong}

Investment from Hong Kong to China has increased dramatically since the early 1980s, and Hong Kong is by far the largest foreign investor in China at present. However, it has been frequently claimed that a significant portion of such invest- 
ment originates from China itself or from countries outside Hong Kong. Much of China's capital outflow that takes place through legal or illegal channels to Chinese firms located in Hong Kong finds its way back to China as FDI. This type of roundtripping of funds is mostly used to escape regulations (e.g., barriers to trade) or to gain eligibility for incentives available only to foreign investors (e.g., tax concessions). According to the World Bank (2002), round-tripping accounts for 20 to 30 percent of FDI in China. Hong Kong is also used as a stepping stone for investment to China: a large number of foreign firms use affiliates in Hong Kong to invest in China on their behalf.

To determine whether Hong Kong's peculiar position leads to different results than those of our core analysis, we eliminate Hong Kong from our sample countries and reexamine the panel analysis. The results are shown in table 2 . Interestingly, we find that the results for all eight countries generally hold when Hong Kong is excluded from the regressions. China's FDI has a significant positive effect on Asian FDI, confirming that there is no negative diversionary effect in terms of the level of FDI inflows to its Asian neighbors. Our results also indicate that FDI inflow can be greatly promoted by reducing the level of corporate tax and by increasing the degree of openness in international trade through lowering tariff and non-tariff barriers and by abolishing various trade impediments (table 2). The importance of establishing a large market is also evident. Corruption appears to have a larger and more significant influence on FDI inflows when the panel is analyzed without Hong Kong. This may be attributed to the fact that Hong Kong demonstrates the lowest level of corruption on average among all countries examined. The importance of the variable may be higher among corrupt economies.

\subsection{Regressions using countries' FDI shares in FDI inflows to Asian countries}

We use a country's share of FDI that goes to Asia as the dependent variable in equation (3) of the model to see whether an increase in China's FDI diverts FDI away from the group, reducing their share of total FDI inflows to Asia. Note that the dependent variable in equation (4), for China, is still the level of China's FDI. One might use China's share of the total FDI inflows to Asia rather than the level of China's FDI. However, between 1985 and 2001, FDI in China and the eight East and Southeast Asian countries accounted for 89 percent of the total FDI inflows to Asia. Thus, an increase in China's share of total FDI inflow to Asia would almost certainly ensure a reduction in the East and Southeast Asian countries' share of total FDI inflow. To avoid this, we continue to use the level of China's FDI inflows in the regressions. 
Table 2. Level of FDI inflows without Hong Kong. Random-effects two-stage least-squares regressions (level of FDI inflows = dependent variable)

\begin{tabular}{|c|c|c|c|c|c|}
\hline Independent variables & (1) & (2) & (3) & (4) & (5) \\
\hline CHINA_FDI & $\begin{array}{l}0.4794^{* * *} \\
(7.29)\end{array}$ & $\begin{array}{l}0.5063^{* * *} \\
(7.36)\end{array}$ & $\begin{array}{l}0.5681^{* * *} \\
(7.48)\end{array}$ & $\begin{array}{l}0.5064^{* * *} \\
(7.60)\end{array}$ & $\begin{array}{l}0.5279^{* * *} \\
(7.33)\end{array}$ \\
\hline AGROWTH & $\begin{array}{l}0.5372 \\
(0.68)\end{array}$ & $\begin{array}{l}0.7329 \\
(0.93)\end{array}$ & $\begin{array}{l}0.2450 \\
(0.28)\end{array}$ & $\begin{array}{l}0.6113 \\
(0.77)\end{array}$ & $\begin{array}{l}0.1231 \\
(0.14)\end{array}$ \\
\hline ACORRUPT & $\begin{array}{l}0.3447 \\
(1.39)\end{array}$ & $\begin{array}{l}0.3499 \\
(1.39)\end{array}$ & $\begin{array}{l}0.5552^{* *} \\
(2.01)\end{array}$ & $\begin{array}{l}0.2356 \\
(0.92)\end{array}$ & $\begin{array}{l}0.4711^{*} \\
(1.74)\end{array}$ \\
\hline ADUTY & $\begin{array}{l}0.0253 \\
(0.12)\end{array}$ & $\begin{array}{l}0.07801 \\
(0.37)\end{array}$ & $\begin{array}{l}-0.2907 \\
(-1.32)\end{array}$ & $\begin{array}{l}0.0633 \\
(0.28)\end{array}$ & $\begin{array}{l}-0.0974 \\
(-0.40)\end{array}$ \\
\hline$A G O V$ & $\begin{array}{l}-0.2275 \\
(-1.06)\end{array}$ & $\begin{array}{l}-0.2060 \\
(-0.94)\end{array}$ & $\begin{array}{l}-0.1485 \\
(-0.61)\end{array}$ & $\begin{array}{l}-0.2425 \\
(-1.12)\end{array}$ & $\begin{array}{l}-0.0639 \\
(-0.28)\end{array}$ \\
\hline AWAGE & $\begin{array}{l}-0.1963 \\
(-1.65)\end{array}$ & & & & \\
\hline AOPEN & $\begin{array}{l}1.0261^{* * *} \\
(5.48)\end{array}$ & $\begin{array}{l}1.0620^{* * *} \\
(4.99)\end{array}$ & & $\begin{array}{l}0.8830^{\text {** }} \\
(4.37)\end{array}$ & \\
\hline AILLIT & $\begin{array}{l}0.0233 \\
(0.13)\end{array}$ & $\begin{array}{l}0.0808 \\
(0.45)\end{array}$ & $\begin{array}{l}0.5080^{* * *} \\
(2.85)\end{array}$ & $\begin{array}{l}0.2122 \\
(1.20)\end{array}$ & $\begin{array}{l}0.5310^{\star * *} \\
(3.05)\end{array}$ \\
\hline ACPTAX & $\begin{array}{l}-1.5079^{* * *} \\
(-3.30)\end{array}$ & $\begin{array}{l}-1.6033^{\text {** }} \\
(-3.33)\end{array}$ & $\begin{array}{l}-0.2246 \\
(-0.51)\end{array}$ & $\begin{array}{l}-1.3361^{\text {*** }} \\
(-2.82)\end{array}$ & $\begin{array}{l}-0.2188 \\
(-0.51)\end{array}$ \\
\hline ATEL & & $\begin{array}{l}-0.1359 \\
(-1.40)\end{array}$ & $\begin{array}{l}0.1795^{* *} \\
(2.18)\end{array}$ & & \\
\hline AINCOME & & & & $\begin{array}{l}-0.0148 \\
(-0.12)\end{array}$ & $\begin{array}{l}0.3014^{* * *} \\
(2.78)\end{array}$ \\
\hline Constant & $\begin{array}{l}4.0785^{* *} \\
(2.18)\end{array}$ & $\begin{array}{l}3.0912^{*} \\
(1.79)\end{array}$ & $\begin{array}{l}0.6266 \\
(0.34)\end{array}$ & $\begin{array}{l}2.5455 \\
(1.25)\end{array}$ & $\begin{array}{l}-0.8821 \\
(-0.43)\end{array}$ \\
\hline$R^{2}$ & 0.6546 & 0.6519 & 0.5648 & 0.6447 & 0.5792 \\
\hline$F$-test: $p$-value & 0.0000 & 0.0000 & 0.0000 & 0.0000 & 0.0000 \\
\hline Observations & 114 & 115 & 115 & 115 & 115 \\
\hline
\end{tabular}

Note: $\mathrm{t}$-statistics are reported in parentheses. CHINA_FDI = inward FDI into China. AGROWTH $=$ growth rate of GDP of each Asian country. ACORRUPT = index of corruption of each Asian country. ADUTY = import duty of each Asian country. AGOV = index of government stability of each Asian country. AWAGE = average wage in manufacturing of each Asian country. AOPEN = share of exports and imports in GDP of each Asian country. AILLIT = percentage of people who are illiterate in each Asian country. ACPTAX = corporate tax rate of each Asian country. ATEL = number of telephone mainlines per 1,000 people of each Asian country. AINCOME = per capita GDP of each Asian country.

* Statistically significant at the 10 percent level.

** Statistically significant at the 5 percent level.

*** Statistically significant at the 1 percent level.

Given that direct investment inflows into China and our eight Asian economies constitute the bulk of direct investment into Asia, ${ }^{8}$ it may not be surprising if the regression results show that, out of the total FDI received by Asia, an increase in China's inward FDI reduces an individual country's share. Nonetheless, it is useful to estimate the impact. Our results confirm that an increase in FDI to China undoubtedly decreases the proportion of FDI that each country obtains. A 10-percent increase in the level of China's FDI causes the East and Southeast Asian countries' shares in FDI to Asia to drop by about 2 to 3 percent. Although a larger share of FDI received by China appears to come at the expense of its neighboring countries, FDI promotion

8 A list of countries regarded as constituting Asia is given in appendix B. 
Table 3. Shares of the eight Asian economies' FDI inflows in total FDI inflows to Asia. Random-effects two-stage least-squares regressions (individual country's shares in FDI to Asia $=$ dependent variable)

\begin{tabular}{|c|c|c|c|c|c|}
\hline Independent variables & (1) & (2) & (3) & (4) & (5) \\
\hline CHINA_FDI & $\begin{array}{l}-0.2544^{\text {*** }} \\
(-4.45)\end{array}$ & $\begin{array}{l}-0.2580^{* * *} \\
(-4.31)\end{array}$ & $\begin{array}{l}-0.1974^{\text {*** }} \\
(-3.05)\end{array}$ & $\begin{array}{l}-0.2355^{* * *} \\
(-4.09)\end{array}$ & $\begin{array}{l}-0.2127^{\text {*** }} \\
(-3.47)\end{array}$ \\
\hline AGROWTH & $\begin{array}{l}0.4250 \\
(0.60)\end{array}$ & $\begin{array}{l}0.5296 \\
(0.75)\end{array}$ & $\begin{array}{l}0.2997 \\
(0.39)\end{array}$ & $\begin{array}{l}0.5123 \\
(0.72)\end{array}$ & $\begin{array}{l}0.2810 \\
(0.37)\end{array}$ \\
\hline ACORRUPT & $\begin{array}{l}0.3242 \\
(1.52)\end{array}$ & $\begin{array}{l}0.3913^{*} \\
(1.79)\end{array}$ & $\begin{array}{l}0.6411^{\text {*** }} \\
(2.73)\end{array}$ & $\begin{array}{l}0.2490 \\
(1.14)\end{array}$ & $\begin{array}{l}0.5337^{\text {** }} \\
(2.40)\end{array}$ \\
\hline ADUTY & $\begin{array}{l}0.0093 \\
(0.05)\end{array}$ & $\begin{array}{l}0.0409 \\
(0.22)\end{array}$ & $\begin{array}{l}-0.4181^{* *} \\
(-2.33)\end{array}$ & $\begin{array}{l}0.0285 \\
(0.15)\end{array}$ & $\begin{array}{l}-0.2389 \\
(-1.21)\end{array}$ \\
\hline$A G O V$ & $\begin{array}{l}0.2103 \\
(1.41)\end{array}$ & $\begin{array}{l}0.2545 \\
(1.63)\end{array}$ & $\begin{array}{l}0.1574 \\
(0.92)\end{array}$ & $\begin{array}{l}0.1711 \\
(1.13)\end{array}$ & $\begin{array}{l}0.1622 \\
(1.00)\end{array}$ \\
\hline AWAGE & $\begin{array}{l}-0.1450 \\
(-1.38)\end{array}$ & & & & \\
\hline AOPEN & $\begin{array}{l}0.8312^{* * *} \\
(5.27)\end{array}$ & $\begin{array}{l}0.9072^{\star * *} \\
(5.14)\end{array}$ & & $\begin{array}{l}0.7172^{* * *} \\
(4.28)\end{array}$ & \\
\hline AILLIT & $\begin{array}{l}0.1316 \\
(0.83)\end{array}$ & $\begin{array}{l}0.1153 \\
(0.72)\end{array}$ & $\begin{array}{l}0.4636^{* * *} \\
(2.91)\end{array}$ & $\begin{array}{l}0.2830^{*} \\
(1.83)\end{array}$ & $\begin{array}{l}0.5216^{\text {*** }} \\
(3.38)\end{array}$ \\
\hline ACPTAX & $\begin{array}{l}-1.1312^{\text {** }} \\
(-3.32)\end{array}$ & $\begin{array}{l}-1.2547^{* * *} \\
(-3.54)\end{array}$ & $\begin{array}{l}-0.4255 \\
(-1.23)\end{array}$ & $\begin{array}{l}-1.0379^{* * *} \\
(-2.99)\end{array}$ & $\begin{array}{l}-0.4393 \\
(-1.29)\end{array}$ \\
\hline ATEL & & $\begin{array}{l}-0.1430^{*} \\
(-1.68)\end{array}$ & $\begin{array}{l}0.1322^{*} \\
(1.81)\end{array}$ & & \\
\hline AINCOME & & & & $\begin{array}{l}0.0049 \\
(0.05)\end{array}$ & $\begin{array}{l}0.2605^{* * *} \\
(2.75)\end{array}$ \\
\hline Constant & $\begin{array}{l}3.3251^{* *} \\
(2.30)\end{array}$ & $\begin{array}{l}2.9793 \text { ** } \\
(2.22)\end{array}$ & $\begin{array}{l}2.2319 \\
(1.52)\end{array}$ & $\begin{array}{l}2.2411 \\
(1.44)\end{array}$ & $\begin{array}{l}0.7423 \\
(0.46)\end{array}$ \\
\hline $\begin{array}{l}R^{2} \\
F \text {-test: } p \text {-value }\end{array}$ & $\begin{array}{l}0.5688 \\
0.0000\end{array}$ & $\begin{array}{l}0.5758 \\
0.0000\end{array}$ & $\begin{array}{l}0.4805 \\
0.0000\end{array}$ & $\begin{array}{l}0.5650 \\
0.0000\end{array}$ & $\begin{array}{l}0.4985 \\
0.0000\end{array}$ \\
\hline Observations & 130 & 131 & 131 & 131 & 131 \\
\hline
\end{tabular}

Note: t-statistics are shown in parentheses. CHINA_FDI = inward FDI into China. AGROWTH = growth rate of GDP of each Asian country. ACORRUPT = index of corruption of each Asian country. ADUTY = import duty of each Asian country. AGOV = index of government stability of each Asian country. AWAGE = average wage in manufacturing of each Asian country. AOPEN = share of exports and imports in GDP of each Asian country. AILLIT = percentage of people who are illiterate in each Asian country. $\mathrm{ACPTAX}=$ corporate tax rate of each Asian country. $\mathrm{ATEL}=$ number of telephone mainlines per 1,000 people of each Asian country. AINCOME = per capita GDP of each Asian country.

* Statistically significant at the 10 percent level.

** Statistically significant at the 5 percent level.

*** Statistically significant at the 1 percent level.

could come from the internal economic policy of each country, such as the level of corporate tax and the degree of openness in foreign trade. The influence of openness on FDI is at least twice as large as that of the China effect, and more than four times as large as the China effect in specifications (1), (2), and (4). Similarly, the influence of corporate taxes on FDI is more than three times as large as that of the China effect.

Also evident from table 3 is the much larger and significant effect of corruption, compared with the effects of this variable as shown in table 1. A 1-percent decrease 
in the degree of corruption is associated with a $0.25-0.64$ percentage increase in the individual share in FDI to Asia, depending on the specification of the equation.

\subsection{Regressions with global supply of FDI}

Table 4 shows the results of adding to our equations a new explanatory variable, OUTFLOW $W_{t}$, which is the total amount of the global supply of FDI for year $t$. One potential criticism of our central finding that FDI in China is positively related to FDI in the East and Southeast Asian economies is that this correlation could arise simply because inflows to most economies are dictated by the global supply of capital of that year. In other words, if OUTFLOW $W_{t}$ increases in year $t$, FDI inflows to both China and the eight Asian economies are also likely to increase, thereby generating our main result but without demonstrating that it is clearly related to the China effect we wish to investigate. To control for the supply-side effect of FDI and to isolate the estimation of the China effect, we therefore run our panel simultaneous equation model with the addition of the OUTFLOW variable.

The coefficients representing the China effect are still positive and significant (table 4). The magnitudes of the coefficients, however, are nearly half as large as those in table 1 . The OUTFLOW variable is also positive and significant and has a larger coefficient than that of the CHINA_FDI variable. Other variables that are significant are corporate tax rates, openness, and degrees of corruption. We confirm again that the China effect is positive. As before, other determinants related to policy, institutions, and the global supply of capital have a stronger effect on the inflows of FDI into these Asian economies.

\section{Conclusion}

Is China diverting FDI away from other Asian economies? This is the paramount question on the minds of many academic researchers and policymakers in Asia. Theoretically, China's ability to attract FDI could have both investment-creating effects and investment-diverting effects on Hong Kong, Taiwan, South Korea, Singapore, Malaysia, the Philippines, Indonesia, and Thailand. We empirically estimate the determinants of FDI inflows in these economies over the 1985-2001 period. The standard determinants we consider include GDP growth rates, degrees of openness, corporate tax rates, indexes of corruption, degrees of government stability, illiteracy rates, per capita GDP, tariff rates, wage rates, and proxies of infrastructure. To estimate the China effect, we include the level of China's inward FDI as the dependent variable in the econometric equations. We use a random-effects simultaneous equation model to estimate our coefficients, including the estimation of the coefficient on the China effect. 
Table 4. Level of FDI, with global supply of FDI variable. Random-effects two-stage least-squares regressions (level of FDI = dependent variable)

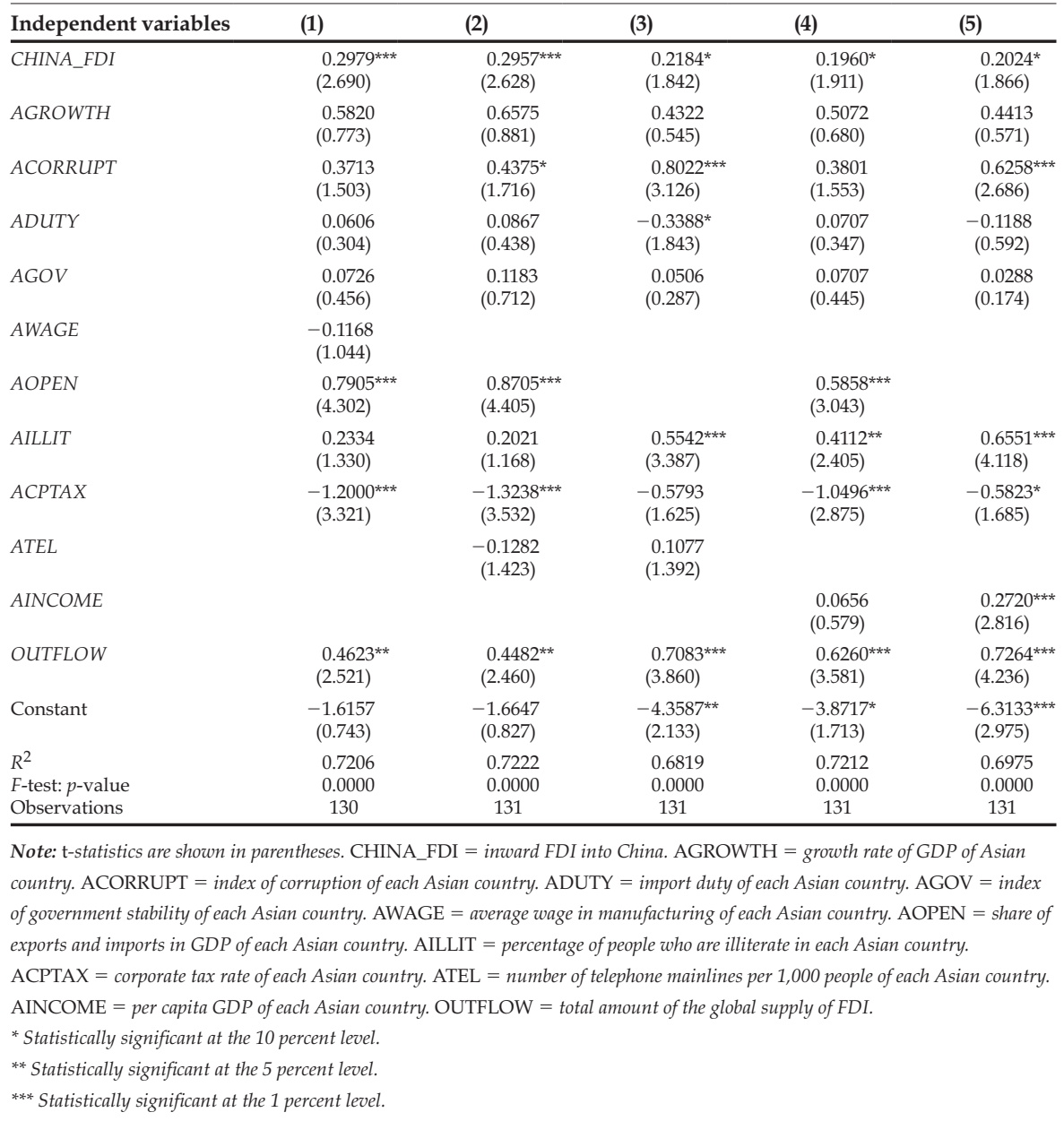

The main results of our paper are as follows. First, in terms of the level of FDI flows, the China effect is positive; that is, FDI inflow to the eight East and Southeast Asian economies is positively related to direct investment in China. Second, in terms of the countries' shares in FDI to Asia, the China effect is negative; that is, although the level of FDI in China and the level of FDI in these eight economies increase together, an increase in China's FDI is associated with a decline in the other economies' share of total FDI inflows to Asia. Third, the China effect is not the most important factor determining the inflows of FDI into these eight East and Southeast Asian economies. Specifically, policy variables such as lower corporate taxes and higher degrees of 
openness play a larger role in attracting investment. In some cases, the regressions indicate that lower degrees of corruption also lead to higher inflows of FDI.

\section{Appendix A. Definitions and sources of data of the variables used in the model}

AFDI and CHINA_FDI: Data on aggregate FDI inflows of each country, aggregate FDI inflows to Asia, and aggregate FDI to the world are from UNCTAD.

ACORRUPT and CCORRUPT: An index of corruption from the International Country Risk Guide (ICRG) from the PRS Group. It ranges from 0 to 6. A higher number means a lower level of corruption.

AGOV and CGOV: An index of government stability from the International Country Risk Guide (ICRG) from the PRS Group. The range is from 0 to 12 . A higher score means higher stability of a government.

ADUTY and CDUTY: Import duties are from the IMF's Government Finance Statistic Yearbook.

AOPEN and COPEN: Openness $=($ export + import $) /$ GDP. Export and import data are from IMF's Direction of Trade.

AILLIT: The illiteracy rate is the percentage of people aged 15 years and above who cannot, with understanding, read and write a short, simple statement on their everyday life. Data are from World Development Indicators.

ACPTAX: Corporate income tax rates, measured in percentage points, are from Price Waterhouse's Corporate Taxes-A Worldwide Summary.

ATEL: Telephone mainlines per 1,000 people. Data are from World Development Indicators.

AINCOME and CINCOME: Per capita GDP (GDP/population). GDP data are from EconStats. Population data are from World Development Indicators (various years). AGROWTH and CGROWTH: GDP growth, measured in percentage points. Data are from EconStats.

AWAGE and CWAGE: Average wage in manufacturing. Data are from United

Nations Common Database, LABORSTA, and countries' official Web sites. OUTFLOW: Total supply of FDI outflows are from UNCTAD.

\section{Appendix B. List of the Asian countries used in the calculations of total FDI in Asia}

Armenia, Azerbaijan, Bahrain, Bangladesh, Bhutan, Brunei Darussalam, Cambodia, China, China Hong Kong SAR, China Macao SAR, China (Taiwan Province of), Cyprus, Georgia, India, Indonesia, Iran (Islamic Republic of), Iraq, Israel, Japan, Jordan, Kazakhstan, Korea (Democratic People's Republic of), Korea (Republic of), 
Kuwait, Kyrgyzstan, Lao People's Democratic Republic, Lebanon, Malaysia, Maldives, Mongolia, Myanmar, Nepal, Oman, Pakistan, Palestinian territory, the Philippines, Qatar, Saudi Arabia, Singapore, Sri Lanka, Syrian Arab Republic, Tajikistan, Thailand, Turkey, Turkmenistan, United Arab Emirates, Uzbekistan, Vietnam, and Yemen.

\section{References}

Bao, Shuming, Gene Hsing Chang, Jeffrey D. Sachs, and Wing Thye Woo. 2002. Geographic Factors and China's Regional Development under Market Reforms, 1978-1998. China Economic Review 13 (1):89-111.

Brainard, Lael S. 1997. An Empirical Assessment of the Proximity-Concentration Trade-off between Multinational Sales and Trade. American Economic Review 87 (4):520-44.

Carr, David L., James R. Markusen, and Keith E. Maskus. 2001. Estimating the KnowledgeCapital Model of the Multinational Enterprise. American Economic Review 91 (3):693-708.

Chantasasawat, Busakorn, K. C. Fung, Hitomi lizaka, and Alan Siu. 2004a. Foreign Direct Investment in China and East Asia. Working Paper no. 233. Stanford, Calif.: Stanford Center for International Development (SCID).

2004b. Foreign Direct Investment in East Asia and Latin America: Is There a PRC Effect? Asian Development Bank Institute Discussion Paper no. 17. Tokyo: Asian Development Bank.

EconStats. Available at http://www.econstats.com

Eichengreen, Barry, and Hui Tong. 2005. Is China's FDI Coming at the Expense of Other Countries? Unpublished manuscript. University of California, Berkeley, and Bank of England.

Fung, K. C., Hitomi Iizaka, and Alan Siu. 2003. Japanese Direct Investment in China. China Economic Review 14 (1): 304-15.

Gastanaga, Victor M., Jeffrey B. Nugent, and Bistra Pashamova. 1998. Host Country Reforms and FDI Inflows: How Much Difference Do They Make? World Development 26 (7):1299-314.

Hines, James R., Jr. 1995. Forbidden Payment: Foreign Bribery and American Business after 1977. NBER Working Paper no. 5266. Cambridge: National Bureau of Economic Research.

Horst, Thomas. 1971. The Theory of the Multinational Firm: Optimal Behavior under Different Tariff and Tax Rates. Journal of Political Economy 79 (5):1959-72.

Hsiao, Cheng. 2001. Efficient Estimation of Dynamic Panel Data Models-with an Application to the Analysis of Foreign Direct Investment to Developing Countries. Lecture at the 2001 Econometric Society Far Eastern Meeting in Kobe, Japan, 20-22 July.

International Labor Organization Bureau of Statistics. LABORSTA, an International Labour Office database. Available at http://laborsta.ilo.org

International Monetary Fund. Direction of Trade Statistics (CD-ROM). Washington, D.C.: International Monetary Fund.

—. Various years. Government Finance Statistic Yearbook. Washington, D.C.: International Monetary Fund. 
McKibbin, Warwick, and Wing Thye Woo. 2003. The Consequences of China's WTO Accession on Its Neighbors. Asian Economic Papers 2 (2):1-38.

Price Waterhouse. Various years. Corporate Taxes-A Worldwide Summary. New York: Price Waterhouse Center for Transnational Taxation.

PRS Group. International Country Risk Guide (ICRG) database, table 3B. Available from http://www.prsgroup.com/icrg/icrg.html

United Nations Conference on Trade and Development (UNCTAD). UNCTAD online FDI/ TNC database. See http:// www.unctad.org/Templates/Page.asp?intItemID=3137\&lang=1

United Nations Statistics Division. UN Common Database (UNCDB).

Wei, Shang-Jin. 1997. Why is Corruption So Much More Taxing than Tax? Arbitrariness Kills. NBER Working Paper no. 6255. Cambridge: National Bureau of Economic Research.

World Bank. Various years. World Development Indicators (CD-ROM). Washington, D.C.: International Bank for Reconstruction and Development (IBRD), World Bank.

. 2002. Global Development Finance 2002: Financing the Poorest Countries. Washington, D.C.: World Bank.

Zhang, Kevin Honglin, and Shunfeng Song. 2001. Promoting Exports: The Role of Inward FDI in China. China Economic Review 12 (1):385-96. 